\title{
Kultajyviä ammentamaan!
}

\section{Praktikumiohjaajiksi hakeutuvien motiivit yliopiston ja koulun yhteistyön edellytysten luotaajina}

\author{
ERJASYRJÄLÄINEN \& RIITTA JYRHÄMÄ
}

\begin{abstract}
Artikkelissa kerrotaan tutkimuksesta, jonka keskeinen tutkimuskysymys on: Mitkä ovat kenttäkouluverkostoon pyrkivien opettajien keskeisimmät motiivit ryhtyä opetusharjoitteluyhteistyöhön yliopiston kanssa? Artikkelissa myös verrataan koulukentän ja yliopiston välistä yhteistyömuotoa muualla maailmassa toteutettuihin kumppanuuksiin ja niistä saatuihin kokemuksiin.
\end{abstract}

$\mathrm{O}$ pettajaksi opiskeleminen koostuu sekä teoreettisista että käytännöllisistä opinnoista. Käytäntöä edustavat opetusharjoittelut, joita kutsutaan myös ohjatuiksi harjoitteluiksi tai praktikumeiksi. Opettajankoulutuksen ohjatut harjoittelut ovat varsin keskeisessä asemassa tulevien opettajien muodostaessa käsitystään ammatista ja koulun arkityöstä. Opiskelijat arvostavat opetusharjoittelua ja pitävät sitä yhtenä merkittävimmistä opintojaksoista (ks. esim. Uusikylä, 1990). Zeichner (1990), vertailtuaan neljän eri englanninkielisen maan praktikumikäytänteitä, toteaa harjoittelun merkityksen olevan kiistaton opettajankoulutuksen laadun kannalta. Harjoittelujaksot nivoutuvat aina laajempaan opettajaksi opiskelun kokonaisuuteen, jossa jokaisella osiolla on oma tavoitteellinen ja sisällöllinen tarkoituksensa ja liittymäkohdat muihin opintojaksoihin. Eri koulutusten harjoittelujaksojen tavoitteet vaihtelevat ja on ensiarvoisen tärkeää, että harjoittelujen ohjaajat tuntevat opettajankoulutuksen opetussuunnitelman, erityisesti praktikumiopinnoille asetetut tavoitteet. Harjoittelujaksojen laajuus ja niiden ajoittuminen opinto-ohjelmassa vaihtelevat eri opettajankoulutusohjelmissa ja eri maissa. Suomessa on ollut tapana sijoittaa opetusharjoittelua koulutusohjelman eri vaiheisiin päinvastoin kuin maissa, joissa harjoitellaan yhtäjaksoisesti pidempään (Jyrhämä 2006). Jälkimmäinen käytäntö on esimerkiksi Yhdysvalloissa, jossa opettajaksi opiskelevat toimivat kentällä ennen valmistumistaan kokonaisen lukuvuoden ajan (ks. esim. Sandholz, 2002, 817). Tällöin he toimivat palkatuissa opettajan tehtävissä (Freese, 1999). Kyse on siis eräänlaisesta työharjoittelusta.

Onpa opiskeluun kuuluvan käytännön opetusharjoittelun määrä mikä tahansa, perustuu opiskelijoiden lähettäminen kouluihin yliopiston ja koulujen väliseen yhteistyöhön. Suomalaisessa koulutusjärjestelmässä yliopistojen omat normaalikoulut (harjoittelukoulut) perinteisesti edustavat käytännön kouluelämää ja ovat erityinen opetusharjoitteluun tarkoitettu foorumi. Yhteistyö yliopiston piiriin kuuluvien koulujen kanssa on vakiintunut ja tuottanut jatkuvasti kehittyvää näkemystä opettajaksi opiskelevan tarpeista ja ohjauksen laadusta harjoittelun aikana (ks. Silkelä, 2003; Väisänen \& Atjonen, 2005; Loima, 2004).

Normaalikoulujen lisäksi on ohjattua harjoittelua ollut vaihtelevassa määrin niin sanotuissa kenttäkouluissa. Vuodesta 2002 lähtien Helsingin yliopistossa on kehitetty kenttäkouluverkostoa. Verkoston luominen on lähtenyt liikkeelle sekä koulutuksellisista että yhteiskunnallisista syistä. Koulutuksellisena periaatteena on ensisijaisesti mahdollisuudet monipuolistaa ja täydentää opiskelijoiden opetusharjoittelun kokemuksia ja näin auttaa heitä valmentautumaan paremmin opettajan työhön. Yhteiskunnalliset syyt liittyvät opettajankoulutuksen sekä työelämän välisen tavoitteellisen yhteistyön kehittämiseen, jossa kumppaneilla on mahdollisuus oppia toisiltaan.

Ohjatun harjoittelun laajentaminen normaali- 
kouluista kenttäkouluihin on nähty tärkeänä sekä opettajankoulutuksen laadullisten että määrällisten tarpeiden kannalta. Opettajan pedagogiset opinnot oikeuttavat laaja-alaiseen opettajan pätevyyteen ja senkin vuoksi on tarkoituksenmukaista tarjota monipuolinen opettajan työn praktinen kenttä. Määrällisesti taas kenttäkouluja tarvitaan, koska normaalikoulujen kapasiteetti ei riitä kaikkien harjoittelujen toteuttamiseen. Yliopistolle on tärkeää toimia vuorovaikutuksessa ympäröivän yhteiskunnan kanssa ja vaikuttaa siihen. Se on yksi yliopiston perustehtävistä tutkimuksen ja opetuksen lisäksi. Useissa opettajankoulutuksen arvioinneissa yhteiskunnallinen vaikuttavuus ja erityisesti yhteistyö kentän koulujen kanssa on nostettu esiin. Opettajankoulutuksen uutta opetussuunnitelmaa laadittaessa keskeiseksi periaatteeksi tuli Helsingin yliopistossa, että ainakin yksi harjoittelujakso toteutetaan kenttäkouluissa.

Kenttäkouluverkostoa koskevan laajemman tutkimushankkeen osana tässä artikkelissa kuvatussa tutkimuksessa tarkastellaan opettajien motiiveja ryhtyä ohjaustehtävään. Tutkimuksen lähtökohtana on kenttäkouluverkoston rooli yliopiston ja koulun kumppanuutta (school-university partnership) edistävänä rakenteena. Ratkaisevimpia tekijöitä yhteistyön onnistumisessa ovat verkoston opettajien motiivit ryhtyä yhteistyöhön. Opettajan orientaatio ohjaustehtävään on paitsi olennainen asia onnistuneen yhteistyön kannalta myös tärkeä seikka ohjaajakoulutuksen suunnittelun näkökulmasta.

Kenttäkouluyhteistyötä organisoitaessa kouluilta kysyttiin halukkuutta verkostoitua yliopiston yhteistyökouluksi. Samalla opettajia pyydettiin ilmoittautumaan ohjaajakoulutukseen. Opettajien jättämissä hakemuksissa ilmaistut motiivit kertovat niistä hyödyistä, joita opettajat odottavat yhteistyöstä saavansa. Yksi opettajista ilmaisi 'ammentavansa kultajyviä' päästessään ohjaamaan opetusharjoittelijoita. Tässä artikkelissa kuvatussa tutkimuksessa pyrimme kultajyvä-metaforan kautta valottamaan ohjaustehtävään kohdennettuja myönteisiä odotuksia ja pohtimaan, miten niitä voisi hyödyntää yhteistyön kehittämiseksi.

\section{Koulun ja yliopiston yhteistyön vakiinnuttaminen}

Opettajan työ edellyttää syvällistä ymmärrystä varsin monipolvisesta arkityön todellisuudesta. Välijärvi (2006) toteaa opettajan työn olevan jatkuvaa älyllistä, sosiaalista ja emotionaalista vuorovaikutusta oppilaiden, omien kollegoiden ja vanhempien kanssa. Tieto opettajan työn eettisestä, kompleksisesta ja praktisesta luonteesta on yhä enemmän tuonut kansainväliseen opettajuutta ja opettajankoulutusta koskevaan tutkimukseen yliopiston ja koulun välisen yhteistyön. Tarve integroida kentän opettajien praktista asiantuntemusta opettajankoulutukseen on tunnustettu (Sutherland ym., 2005; Hodkinson ym., 1999).

Helsingin yliopistossa kenttäkouluverkoston organisointi on perustunut kolmeen lähtökohtaan: 1) opettajankoulutuksen opetussuunnitelman toteuttamiseen ja kehittämiseen, 2) yhteistyön kehittämiseen sekä 3) ohjaajakoulutuksen

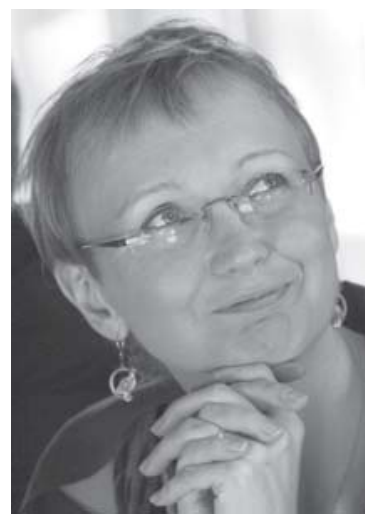

Erja Syrjäläinen

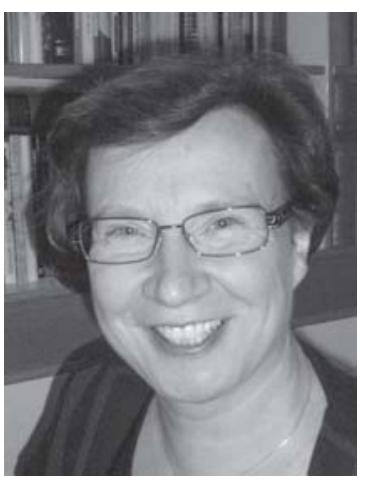

Riitta Jyrhämä toteuttamiseen. Systemaattinen ja pitkäjänteinen ohjaajakoulutus on nähty keskeisenä yhteistyön muotona sekä praktikumien laadun takaajana (ks. Jyrhämä \& Kronlund, 2003; Syrjäläinen \& Meri, 2007, 20). Ohjaajaksi sitoutuessaan kenttäkoulun opettaja asettuu opettajankouluttajan tehtävään ja sitä kautta niihin tavoitteisiin, joita opettajankoulutukselle on asetettu. Opiskelijoiden harjoittelukokemusten yhtenäisyyden vuoksi on tärkeää, että ohjaavien opettajien näkemykset ohjauksen tavoitteista, sisällöistä ja menettelytavoista ovat samansuuntaiset.

Kenttäkouluverkosto luo puitteet yhteistyölle, jossa kunkin osallisen motiivit sitoutua yhteiseen toimintaan ovat ratkaisevassa asemassa. Toisaalta myös ne muodot, joiden avulla yhteistyötä ylläpidetään vaikuttavat siihen, miten mielekkäänä yhteistyö nähdään. Winitzkyn ym. (1992, 12) mukaan yksi yhteistyön kriittisistä kohdista on yhteistyöorganisaation toimivuus: millaisin organisatorisin toimin, tapahtumin ja neuvotteluin osapuolet sitoutetaan yhteistyöhön ja sen arviointiin. Koulun ja yliopiston opettajankoulutuksen välisen kumppanuusyhteistyön muotoja ja vaiku- 
tuksia on tutkittu aktiivisesti 1990-luvun alusta lähtien. Yhdysvalloissa koulujen ja yliopistojen yhteistyö järjestetään usein nk. PDS-mallin (professional development school) mukaan, joka noudattaa kolmea periaatetta: valmistaa tulevia opettajia, edistää käytännön opetustyötä tekevien ammatillista kasvua ja rohkaista kasvatuskäytäntöön liittyvää tutkimusta (Sandholz, 2002; Winitzky ym., 1992; Stevens, 1999). Kirschenbaum ja Reagan (2001) toteavat, että 1990-luvun alusta lähtien on Amerikassa ollut yliopistojen ja koulujen kumppanuusyhteistyön nousukausi.

Yliopiston opettajankoulutus ja kentän oppilaitokset ovat kaksi erilaista organisaatiota, joissa vallitsevat erilaiset kulttuurit. Yhteistyössä nousee esiin kysymyksiä, jotka ovat tuttuja mistä tahansa eri kulttuurien välisestä yhteistyöstä: kenen ehdoilla toimitaan ja kuinka otetaan joustavasti huomioon molempien kulttuurien pelisäännöt ja toimintatavat? Organisaatioiden rajavyöhykkeellä olevan sillan rakentaminen vaatii kumppaneilta erityisiä panostuksia (Edwards \& Mutton, 2007; Firestone \& Fisler, 2002). Puhutaan rajamaastossa tehtävästä työstä, joka ei varsinaisesti kuulu kummankaan organisaation työntekijöiden tehtäväkenttään ja jonka avulla pyritään löytämään mahdollisimman joustavia yhteistyömuotoja. Voidaan puhua kahden instituution välisen kollaboratiivisen infrastruktuurin luomisesta.

Ricen (2002) mukaan opetusharjoitteluyhteistyössä keskeisimmät ongelmat ovat siinä, että yliopiston ja opettajaksi opiskelevien tavoitteet ovat erilaiset kuin koulun opettajien. Tästä syystä onkin mielenkiintoista tutkia, minkä laatuisia motiiveja kentän opettajilla liittyy yhteistyöhön ja ohjaajuuteen ja mitä ne merkitsevät ohjaajakoulutuksen suunnittelun ja opetusharjoittelun järjestämisen kannalta.

Rice (emt.) toteaa myös, että ensisijaisin yhteisesti koettu hyöty koulun ja yliopiston välisissä kumppanuushankkeissa liittyy opettajien ammatilliseen kehitykseen. Borthwick ym. (2003) haastattelivat kymmenen eri kumppanuushankkeen osallisia, joiden näkemysten mukaan yhteistyön hyödyt ovat ammatillinen kehittyminen, resurssien lisääntyminen, kollegiaalisen yhteistyön tuottama tuki sekä opiskelijoiden saamat hyödyt. Sandholz (2002), joka keskittyi tutkimuksessaan ammatillista kehittymistä edistäviin tekijöihin, tiivisti opettajien saaneen voimakkaimmat kokemukset tällä alueella oppiainekohtaisista tai opetusta koskevista tapaamisista, kollegiaalisesta vuorovaiku- tuksesta ja opettajaopiskelijoiden ohjaustyöstä. Sandholziin vedoten voi todeta, että opetusharjoittelun ohjaustyö on yksi ammatillisen kehittymisen väylä. Lopez-Realin ja Kwanin (2005) tutkimustulosten mukaan opetusharjoittelun ohjaajina toimivat opettajat oppivat analysoidessaan harjoittelijalle omaa työtään, nähdessään opiskelijoiden kehittelevän uusia ideoita, hyödyntävän informaatiota ja uusia opettamisstrategioita sekä käyttävän tieto- ja viestintätekniikkaa hyödyksi opetuksessa.

Opetusharjoittelu on luonnollinen osa yliopiston ja koulun välistä yhteistyötä. Se toimii siltana opiskelijan akateemisten opintojen sekä hänen tulevan opettajan työnsä välillä. Harjoittelu tuo mukanaan sellaista opettajuuteen liittyvää implisiittistä ja käytännöllistä tietoa, jota ei voi muulla tavoin saavuttaa. Tynjälä (2004; 2007) toteaa asiantuntijan osaamisen koostuvan teoreettisen (käsitteellisen) ja käytännöllisen (kokemuksellisen) tiedon lisäksi toiminnan säätelyä koskevasta tiedosta, joka tulee esiin muun muassa noviisin ja ekspertin välisissä ohjaustilanteissa. Asiantuntijan epämuodollinen tieto teoriasta ja käytännöstä erilaisissa ongelmanratkaisutilanteissa tuottaa juuri tällaista toiminnan säätelyä koskevaa tietoa.

Praktikumin ohjaus pakottaa miettimään opettajan omia pedagogisia ratkaisuja ja tällöin ohjaavan opettajan tietoisuus vastuusta pedagogina kasvaa. Kyse on siis eräänlaisesta työssä oppimisesta, joka kentällä toimivan ohjaajan osalta on luonteeltaan informaalia. Ohjaajien ja opiskelijoiden dialogi voisi vertautua Järvisen ym. $(2000,103)$ toteamukseen: "Kyse ei ole vain tekemällä oppimisesta ... Olennaista on tekojen ja toiminnan reflektointi sekä kokemusten jakaminen muiden kanssa.” Onhan tämä tietenkin mahdollista opettajien kesken tavanomaisessa kouluelämässä ilman opetusharjoittelijoiden läsnäoloakin, mutta opettajaksi opiskelevat antavat reflektoinnille sysäyksen ja ohjaavalle opettajalle 'legitiimin' oikeuden ajatella ääneen. Ilmeisesti opetusharjoittelijoiden läsnäololla kouluissa on myös kouluyhteisölle innovoivaa vaikutusta, näin ainakin monet rehtorit ja opettajat kertovat. Kysymys opettajaksi ja opettajana kasvamisesta on yhteinen sekä opettajankoulutukselle että opettajan työssä toimivalle. Kumppanuusyhteistyö tarjoaa mahdollisuuden yhteiseen pohdintaan. 


\section{Tutkimuksen toteuttaminen}

Ohjaajakoulutukseen hakeutumalla opettajat ja heidän koulunsa saivat mahdollisuuden ilmaista halukkuutensa kenttäkouluverkostoyhteistyöhön. Vuosina 2004-2006 ohjaajakoulutuksen verkkolomakkeet olivat avoinna neljästi ja yhteensä 460 opettajaa 117 koulusta tai oppilaitoksesta hakeutui koulutukseen. Hakijoita oli peruskoulusta, lukiosta, vapaasta sivistystyöstä, yksityisistä opistoista ja ammattikorkeakouluista. Ohjaajakoulutusta (8 op) järjestettiin ko. vuosina neljästi. Näistä yksi koulutusjakso oli ruotsinkielinen.

Tässä artikkelissa raportoitavan tutkimusosuuden tutkimuskysymys on: Mitkä ovat kenttäkouluverkostoon pyrkivien opettajien keskeisimmät motiivit ryhtyä opetusharjoitteluyhteistyöhön yliopiston kanssa? Hakijoita ohjaajakoulutukseen oli enemmän kuin kyettiin ottamaan. Hakijoiden runsas määrä kertoo kiinnostuksesta ohjaajan tehtävää kohtaan. Erittelemällä ohjaajaksi aikovien motiiveja saadaan tarkempi käsitys siitä, miksi opetusharjoittelun ohjaus kiinnostaa. Motiivit antavat kuvaa opettajien henkilökohtaisesti kokemista ohjaustyön hyödyistä, mutta samalla ne antavat pohjaa kenttäkouluyhteistyön edellytysten tarkastelulle. Motiivit kuvaavat sitä, millaisen kontribuution kentän opettajat ovat valmiita ohjaustyön kautta antamaan opettajankoulutukselle.

Ohjaajakoulutuksen hakulomakkeissa esitettiin avoin kysymys ohjaajaksi hakeutuvan motiiveista. Vastaajalta kysyttiin: "Miksi haluat ohjaajakoulutukseen? Tee tiivistetty luettelo keskeisimmistä motiiveistasi." Vastauslomakkeessa oli tukilauseena lisäksi: "Minua kiinnostaa opetusharjoittelun ohjaajana toimiminen, koska..."

Yhteensä 460:stä opettajasta vain neljä jätti vastaamatta tähän kysymykseen. Jokainen hakija ilmaisi 1-11 erilaista motiivia omassa vastauksessaan. Kunkin vastaajan vastauksesta eriteltiin erilaatuisia motiiveja ilmaisevat lauseet, joita kertyi kaikilta vastaajilta yhteensä 1644. Tämä data oli sisällönanalyysin kohteena. Ilmaistuja motiiveja luettiin läpi useaan kertaan ja jäsennettiin vaihe vaiheelta. Toinen tämän artikkelin kirjoittajista suoritti huolellisen toistuvan lukemisen pohjalta luokittelun aineistosta nouseviin peruskategorioihin. Tämän jälkeen reliabiliteetin varmistamiseksi toinen analysoi noin 400 motiivilausetta. Sen seurauksena todettiin rinnakkaisluokittelun tuottavan 93,7 prosenttin yksimielisyyden.

\section{Praktikumiohjaajaksi hakeutumisen motiivit}

Analysoinnin tuloksena muodostui kaksitoista ohjaajaksi hakeutumisen motiiviluokkaa, joista yksi oli tarkemmin luokittelematon "muut". Kolme ensimmäistä pääluokkaa sisältää 58.8 prosenttia kaikista motiiveista, joista tärkeimmiksi nousivat omaan ammatilliseen kehittymiseen liittyvät motiivit. Taulukossa 1 on kuvattu analyysin tuloksena saadut kategoriat sekä niiden painoarvo suhteessa toisiinsa. Koska ensimmäinen kategoria, ammatillinen kehittyminen, käsitti yli kolmanneksen kaikista motiivilauseista, teimme jatkoanalyysin kaikista tähän luokkaan sisältyneistä motiiveista. Näin saimme tarkemman kuvan siitä, mitä ohjaajiksi aikovat sisällyttävät ammatillisen kehittymisen piiriin. Seuraavissa luvuissa käsittelemme sekä taulukossa kuvattujen peruskategorioiden sisältöjä että edellä mainitun jatkoanalyysin tuloksia.

\section{Ammatillinen kehittyminen keskeisenä yhteistyöhön hakeutumisen motiivina}

Opettajat liittivät ammatilliseen kehittymiseensä monenlaisia näkökulmia. He näkivät, että nimenomaan ohjaajana toimiminen antaa mahdollisuuden ammatillisen otteen uudistumiseen. Kiteyttäen näitä motiivi-ilmaisuja voisi kuvata seuraavanlaisina iskusanoina: syventäminen, peilaaminen,

Taulukko 1. Motiiviluokat (\%)

Motiiviluokka

Oma ammatillinen kehittyminen

Opettajuuden kokemusten jakaminen

Vuorovaikutuksellisuus

Opettajan erityisosaaminen

Koulun, luokan tai opettajan

mahdollistamat opiskeluolosuhteet

Harjoittelun virkistävä vaikutus oppi-

laisiin, luokkaan ja koulun arkeen

Yhteistyö yliopiston kanssa

Aiemmat kokemukset ohjaustyöstä

Opettajan oma opiskelumotivaatio

Omat kokemukset opetusharjoittelusta

Opettajan ominaisuudet, luonteen-

piirteet

Muita motiiveja

6.0
36.9

11.4

10.5

8.5

7.6

4.5 $\%$

更




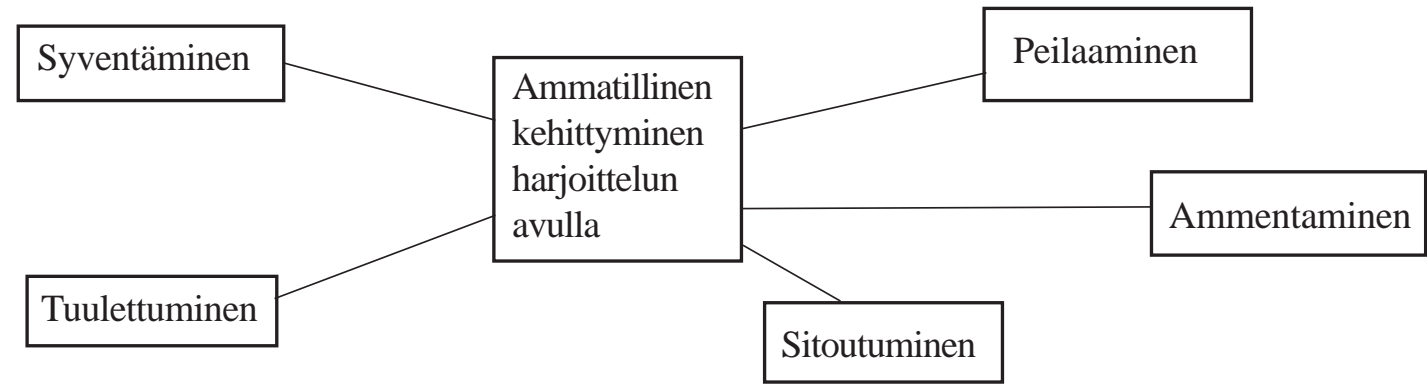

ammentaminen, sitoutuminen ja tuulettuminen (ks. kuvio 1).

Syventäminen tarkoittaa ammatillista syventymistä ja motivoitumista. Useat hakijat viittasivat teoreettisen ja praktisen pedagogisen osaamisen kohtaamiseen, jolloin ammattitaito uudistuu ja laajentuu.

Nyt mielestäni ‘työyhtälöön’ voisin lisätä uuden muuttujan.

Haasteellista opettaa opettajuutta kokonaisuutena.

Voin samalla syventää omaa ammattitaitoani. Samalla voi myös pyrkiä oman ammatillisuuden ja ammattitaidon analysointiin ja kehittämiseen.

Näen ohjaajana toimimisen mahdollisuutena kehittyä omassa työssä.

Haluan tutkia opettajan työtä myös metatasolla teorioiden kautta.

Ohjaajana toimiminen merkitsisi erinomaista mahdollisuutta kehittyä opettajan työssä ja syventyä opettajan ammattiin taas aivan uudella tavalla.

Handledningen kan även hjälpa mig att utvecklas i mitt läraryrke.

Jag tror på livslångt lärande, och ser denna uppgift som en möjlighet även för mig själv att fördjupa mig i mina ämnen, och utveckla mina pedagogiska metoder.

Peilaamisesta voidaan puhua opettajien kuvatessa omien toimintatapojensa perustelemista, kyseenalaistamista ja arviointia. Opettajat ilmaisivat, että ohjatessaan muita opettajuuteen, he joutuvat itse perustelemaan ja kyseenalaistamaan omaa työtään ja omia toimintatapojaan, jolloin tietoisuus kasvaa ja pääsee päivittämään osaamistaan. Opetuksen suunnittelu- ja kehitystyö vaatii ohjauksen yhteydessä analyyttisyyttä ja mahdollistaa luontevasti sellaisen ammatillisen ja kollegiaalisen keskustelun, jota ei tavanomaisesti käydä arjessa. Ohjaustehtävän kautta opettaja saa uuden peilin työhönsä ja voi näin nähdä työnsä uudesta näkökulmasta. Odotetaan myös, että opettajan oma persoonallinen työote vahvistuu samalla, kun ohjaa opetusharjoittelijaa käyttämään omaa persoonaansa opetustyössä.

Se on samalla oman työn arviointia, jäsentämistä ja kehittämistä.

Uskon tulevien opettajien ohjaamisen kehittävän myös itseäni opettajana.

Joudun arvioimaan ja tarkastelemaan omaa työtäni tarkemmin, kun sitä seuraavat läheltä myös harjoittelijat.

Opetusharjoittelijat tuovat mukanaan kysymyksen miksi tehdään näin, miksi menetellään näin ja sitä on hyvä miettiä kokeneenkin opettajan.

Seuratessa ja ohjatessa toisen tunteja tulee kyseenalaistaneeksi omat menetelmänsä ja toivottavasti tuulettaneeksi niitä.

Ammentaminen tarkoittaa opettajille oman opetuksen ja oppilasryhmien avautumista uusin silmin. Vastaajat puhuivat 'kultajyvistä', joita on mahdollista saada ajatusten, ideoiden, virikkeiden ja uusien näkökulmien avulla. Harjoittelijoiden kautta opettajat tutustuvat lähestymistapoihin, jotka antavat uutta innostusta ja perspektiiviä työhön ja samalla oppivat omista oppilaistaan uusia asioita.

Ainedidaktisen tuoreuden säilyttäminen.

Sen avulla saan itsekin viimeisintä tietoa alalta ja voin kehittyä opettajana jatkuvasti. Pystyn tarkkailemaan oppilaita 'eri silmin'.

Ohjaajana toimimisessa on mahdollisuus saada uusinta tietoa oman alan pedagogiikasta. Uusimpien alan trendien seuraaminen onnistuu opiskelijoiden välityksellä helposti ja oma työni saa virikkeitä. 
Oman työn kannalta nuorten opettajien kanssa toimiminen on hedelmällistä.

Sitoutuminen työhön viittaa opettajan omaan perusasenteeseen, jolla hakija kuvaa sitä vakavuutta, jolla hän tehtävänsä opettajana kokee. Sitoutumisen kautta syntyvä motivaatio työhön heijastelee myös samalla opettajan halua ohjata tulevia opettajia. Persoonallinen sitoutuminen opettajuuteen on myös samalla sitoutumista auttamaan opetusharjoittelijoita löytämään omaa opettajuuttaan.

Olen kiinnostunut ja edelleen innostunut työstäni ja ohjaus antaa siihen uutta näkökulmaa. Undervisning är en av mina passioner och jag skulle gärna bli bättre på att handleda feltpraktikanter.

Päivitän opetustani jatkuvasti ja toivon oman innostukseni tarttuvan myös tuleviin opiskelijoihin.

Tuulettuminen merkitsee opettajille urautumisen välttämistä. Ohjaajana toimiminen 'antaa virtaa' ja pitää ajanhermolla sekä innostaa. Ohjaustyön koetaan antavan mielekkyyttä, ryhtiä ja 'tsemppiä' arkityöhön. Se monipuolistaa työnkuvaa, vahvistaa työmotivaatiota, estää sammaloitumista, leipääntymistä ja johtaa pois urautumisesta.

Urautumisen estohoitoa.

Haluan saada jotain uutta (ja vaihtelua) omaan työhöni.

En halua rutinoitua liikaa omiin tapoihini vaan haluan kehittää opetustani ajan hengen mukaan.

Ohjaajana toimiminen tuo lisää mielekkyyttä myös omaan työhöni, ryhtiä, ei ole mahdollisuutta kangistua vanhoihin kaavoihin.

\section{Muut yhteistyöhön ja ohjaajakoulutuk- seen hakeutumisen motiivit}

Opettajuuden kokemusten jakaminen $(11,4 \%)$ on monien työvuosien ja pitkän kokemuksen ansiosta merkityksellistä, sillä ohjaajiksi aikovat kokevat hallitsevansa kokonaiskuvan opetustyöstä. Monilla on muistoissa niitä tilanteita, jolloin aloittelevana opettajan sai olla kokeneemman opettajan perehdytyksessä. Vuosien myötä kertynyt kokemus antaa varmuuden siitä, että on jotain annettavaa. Ohjaava opettaja antaa ideoita, kokemusta, vaihtoehtoja ja keskusteluaikaa sekä oppilasryhmän, jolloin opiskelija löytää vahvuutensa ja ohjaajat voivat olla helpottamassa aloittelevan opet- tajan vaikeuksia.

Toisaalta tunnen olevani jo kertyneen kokemukseni perusteella ammattitaitoinen opettaja, ja uskon että minulla on annettavaa nuorille valmistuville opettajille.

Uskon, että pystyn myös antamaan arvokasta, kokemuksen tuomaa tietoa opiskelijoille.

Voin antaa opiskelijalle hitusen parasta osaamistani ja käytännön tietoa useilta työvuosilta.

Koska olen toiminut alalla jo näinkin kauan, luulen kykeneväni antamaan harjoittelijoille sen olennaisimman tiedon, mitä tässä työssä tarvitaan.

Vuorovaikutuksellisuus (10,5 \%) nähdään vastavuoroisuutena, kohtaamisena, joka on arvo sinänsä. Kokeneet opettajat haluavat tukea nuoria opettajaksi opiskelevia ja innostaa heitä opettajuuteen kasvussa. Nuoren opiskelijan kohtaaminen nähdään virkistävänä ja häntä halutaan pitää aikuisena yhteistyökumppanina, kollegana. Mahdollisuus keskusteluun ja kontaktien luomiseen on arvokasta. Yhteisen kielen löytäminen ja tilan luominen keskustelulle sekä vuorovaikutteisuuden kehittäminen koetaan tärkeänä. Palautteen antaminen on osa vuorovaikutusta ja se nähdään haasteellisena. Vuorovaikutteisuudella on suoria seurannaisvaikutuksia: opettaja ja ohjattava sekä työyhteisö kehittyvät ja siirtovaikutus oppilaisiin päin tulee luonnostaan.

Olen kiinnostunut vuorovaikutuksesta.

Odotan innolla niitä hedelmällisiä pedagogisia keskusteluja, joita harjoittelijoiden kanssa viriää.

För att jag tycker det vore givandet att få möta blivande lärare.

Ohjaajana toimiminen oli mielenkiintoinen tapa saada omaan yksinäiseen aineenopettajan työhön vuorovaikutusta ja raikkaita uиsia tuulia.

Ohjaajan ja ohjattavan suhde on vuorovaikutusta, josta kumpikin saa paljon.

Opettajan erityisosaaminen (8,5 \%), joka liittyi esimerkiksi oppiaineeseen, tieto- ja viestintätekniseen osaamiseen, hallinnolliseen tai yhteiskunnalliseen aktiivisuuteen tai ammattiyhdistystoimintaan, mainittiin erityisenä motiivina hakeutua ohjaajaksi. Myös kokemukset maaseudun kouluista tai opetustyöstä ulkomailla katsottiin hyödyllisiksi harjoittelun ohjaustyössä. Lisäksi mainittiin yh- 
teistyö vanhempien ja viranomaisten kanssa. Monet kokivat erityspedagogisella osaamisella olevan merkitystä ohjaajaksi tarjoutumisessa.

Kaupungin konsultoivana opettajana toimin historian opettajien kouluttajana, joten ohjaaminen on luonnollinen osa työtäni.

Erityisen tärkeää on mielestäni systeemin tuntemus eli miten koulun käytänteet toimivat ja syntyvät. Tästä minulla on monipuolista kokemusta mm. toimimisesta kouluni johtoryhmän jäsenenä.

Minulla on opiskeluajoilta myös kokemusta aikuisopetuksesta.

Haluan ja pystyn antamaan tietoa: verkkoopetuksesta.

Koulun, luokan ja opettajan mahdollistamat opiskeluolosuhteet (7,6 \%) nähtiin erityisenä vahvuutena ja ylpeyden aiheena, jonka vuoksi opettaja ja koulu olisivat soveliaita ottamaan vastaan opetusharjoittelijoita. Koulun opiskeluilmapiiriä tai työyhteisön ilmapiiriä pidettiin harjoittelun kannalta antoisana. Erityisoppilaiden tai maahanmuuttajataustaisten mukanaolo opetusryhmissä nähtiin etuna. Koulun tilat ja sijainti sekä oppiainekohtaiset tilat mainittiin myös soveliaiksi harjoittelua ajatellen. Jotkut koulut olivat pilottikouluja tiettyjen kokeilujen suhteen, mainittiin mm. oppimiskäsitys ja sen käytännön toteutus, integrointi, projektit, painotusalueet, kansainvälisyys tai kieliohjelma. Toisaalta eräät mainitsivat, että koulu on aivan tavallinen koulu ja sitä pidettiin opetusharjoittelua ajatellen ansiona.

Koulumme tarjoaa hyvät mahdollisuudet erilaisten työtapojen käyttöön mm. tietokoneiden avulla multimedialuokassa.

Haluan antaa opetusharjoittelijoille mahdollisuuden tutustua kenttäkouluun, joka on vireä ja aktiivinen, tavallinen koulu.

Mielestäni koulumme on turvallinen ja mukava ympäristö opetusharjoittelijoille.

... tarjota tuleville opettajille miellyttävän ja kasvattavan harjoittelukokemuksen oppilaideni kanssa (heistä kolmasosa maahanmuuttajia).

Koulussamme toimii yleisopetuksen ja erityisopetuksen rinnakkaiselo ja integraatio luontevasti.

Harjoittelun virkistävä vaikutus oppilaisiin, luokkaan ja koulun arkeen (4,5 \%) nähtiin piristysruiskeena ja opetusta monipuolistavana. Mui- den aikuisten tulo luokkaan tarjoaa oppilaille vaihtelua. Harjoittelijoiden läsnäolo rikastuttaa opetusta ja koulun elämää.

Myös oppilaani suhtautuvat myönteisesti useampaan aikuiseen luokassa, ja toiseen opettajaan.

Oppilaille on hyvää harjoitusta tutustua useisiin aikuisiin ja opetustyyleihin.

Eleverna och undervisningen mår bra av förnyelse, variation, flexibiletet och god planering.

Uskoisin myös oppilaiden olevan motivoituneimpia kun asiat tulevat opetettua erilaisin menetelmin.

Yhteistyö yliopiston kanssa (3,8 \%) kehittää. Harjoittelun ohjaajana toimiminen ja ohjaajakoulutus tarjoavat tilaisuuden sekä verkostoitumiseen yliopiston suuntaan että muiden ohjaajana toimivien suuntaan. Opettajat ilmaisivat myös kiinnostuksen opettajankoulutusta kohtaan.

Yhteistyö opetusharjoittelijoiden kanssa on yksi tilaisuus pysyä ajan tasalla ja ikkuna yliopistossa ja normaalikouluissa tapahtuvaan opetustyön kehittämiseen.

Att hålla mig à jour med utbildningen och hålla kontakt till universitetet.

Att hänga med i de senaste rönen på universitetet.

Pidän myös erittäin tärkeänä tiedekorkeakoulun ja ammattikorkeakoulun välistä dialogia.

Haluan olla mukana, vaikkakin pienenä linkkinä, opettajien koulutuksessa.

Aiemmat kokemukset ohjaustyöstä (3,5 \%) rohkaisivat ennenkin ohjanneita tarjoutumaan jatkoon. Ohjaustyö on koettu positiivisena ja antoisana ja opettaja on saanut hyvää palautetta toiminnastaan sekä opiskelijoilta että didaktikoilta.

Minulla on hyviä, aikaisempia kokemuksia opiskelija-ohjauksesta.

Olen ollut Normaalikoulussa vuoden luokanlehtorina ja jo silloin pidin ohjaajan työstä, tulin hyvin toimeen ohjattavien kanssa.

Olen saanut paljon positiivista palautetta harjoittelijoiltani.

Minua kiinnostaa opetusharjoittelun ohjaajana toimiminen, koska olen tehnyt sitä aikaisemmin. Tiedän, mitkä ovat ohjaamisen edut ja haitat. 
Opettajan oma opiskelumotivaatio (2,9\%) oli yksi tärkeä ohjaajaksi hakeutumisen motiivi. Muutamat kuvasivat innostustaan opiskeluun sen kautta, että heillä on vireillä muitakin opiskeluhankkeita. Monet mainitsivat vain yleisesti halun oppia ja opiskella sekä eräät myös halunsa ryhtyä jatko-opiskelijaksi.

Ohjaajan opinnot kiinnostavat, saisin varmastikin apuja miettiä oppimistapahtumien ohjausta itse opettajana ja ennen kaikkea juuri opiskelijoiden työn ohjaajana.

Haluan saada lisää pedagogista koulutusta. Ikuinen halukkuus oppia lisää ja jakaa opittua myös muille.

Omat kokemukset opetusharjoittelusta (2,2\%) ovat saattaneet olla joko positiivisia tai negatiivisia, mutta ne ovat toimineet pontimena hakeuduttaessa itse ohjaajiksi. Hyvän palautteen tärkeyttä korostettiin, samoin sitä, kuinka merkittävä ja mieleenpainuva jakso harjoittelu oli omassa opettajaksi kehittymisessä ollut.

Koin itse harjoittelut mielekkäinä ja sain niistä paljon opiskeluaikana.

Itselläni oli hyvät muistot kenttäharjoittelusta. Sain paljon arvokasta opastusta ja kannustusta.

Olen itse saanut opiskeluaikana monenlaista ohjausta ja toivon, että kukaan opetusharjoittelija ei tule masennetuksi ja alistetuksi ohjauksessa.

Omat harjoittelut ovat vielä melko tuoreessa muistissa, joten minulla on aika vahvat mielikuvat saamani ohjauksen heikoista ja vahvoista puolista, mistä oletan olevan hyötyä ohjaajana toimiessa.

Opettajan ominaisuuksina tai luonteenpiirteinä (2,2\%) vastaajat toivat esiin henkilökohtaisia piirteitään, kuten innovatiivinen, ohjaustyöhön soveltuva, energinen, avoin ja sosiaalinen. Mainitsipa joku erityiseksi ansiokseen senkin, että hän on mies.

Olen myös mielestäni innostunut, ahkera, kekseliäs, hyvä keskustelija ja palautteen antaja. Näistä ominaisuuksista katson olevan hyötyä "hyvälle" ohjaajalle.

Minulla on aina ollut hyvät suhteet oppilaisiin ja tulen hyvin toimeen ihmisten kanssa. Olen avoin, innostunut ja uteliaskin. Själv är jag innovativ och söker nya utmaningar.
Muita motiiveja (6,0 \%) oli mm. saada uutta opettajamateriaalia omaan kouluun tai oppilaitokseen. Edelleen mainittiin, että koska ystäviä on töissä normaalikouluissa, saa siitä innostusta. Lisäksi mainittiin yleinen halu auttaa, mikäli ohjaajista on pulaa, tai nähtiin kenttäkouluverkoston idea niin hyvänä, että pelkästään sen vuoksi kannattaa olla mukana.

\section{Opettajien motiivit yhteistyöedellytysten heijastajina}

Kenttäkouluverkoston organisoinnin myötä on ollut yllättävää havaita kentän opettajien laaja kiinnostus opetusharjoittelun ohjaukseen. Noin 350 kaikista 460 ohjaajakoulutukseen hakeutuneesta opettajasta aloitti ohjaajakoulutuksen vuosina 2004-2006. Vuoden 2008 kuluessa koulutetaan vielä noin 150 opettajaa lisää. Miten on ymmärrettävissä tällainen kiinnostus sitoutua opetusharjoitteluyhteistyöhön yliopiston kanssa? Alkaisiko liki kolmekymmenvuotinen akateeminen, reflektiivistä käytäntöä korostava opettajankoulutus kantaa nyt hedelmää? Tässä kuvattu tutkimus ei oikeuta näin laajaan johtopäätökseen, mutta ehkä tätäkin näkökulmaa kannattaa pohtia. Yksi keskeinen seikka on, että opettaja tekee ohjaustyötä omalla työpaikallaan. Ammatillisen kehittymisen voimakas korostuminen, samoin kuin halu ylpeänä tuoda oman koulun olosuhteet, oma erityisosaaminen ja oppilaat harjoittelun piiriin kertovat siitä, että opettajat kokevat harjoittelun rikastuttavan heidän arkista koulutyötään. Vuosien myötä karttunut kokemus opetustyöstä koetaan niin arvokkaaksi, että siitä voi jakaa edelleen tuleville opettajille. Yhteistyö ilmenee ensisijaisesti siten, että yliopisto tulee "harjoittelijan muodossa" opettajan työpaikalle. Pohtiessaan opettajien täydennyskoulutuksen muotoja Sandholz (2002) antaa samankaltaisia viitteitä: opettajat kokivat palkitsevimpana sellaiset toiminnot, joissa oman työn arkiset kysymykset tuodaan keskustelun ja jakamisen piiriin ja näin mahdollistetaan ammatillinen oppiminen.

Luukkainen (2005) toteaa, että yhteistyön lisääntyminen opettajan työssä on tärkein tulevaisuudessa tapahtuva muutos. Yksilökeskeisestä opettajakulttuurista siirrytään yhteisökeskeiseen kulttuuriin, jossa koulun sisäiset ja ulkopuoliset kasvatuskumppanit otetaan yhä voimakkaammin huomioon. Vuorovaikutuksellisuuden ja jakamisen teemojen ilmeneminen opettajien motiiveissa antavat viitteitä tähän Luukkaisen osoittamaan suuntaan. 
Vaikka motiivikategorioissa erikseen mainittu "yhteistyö yliopiston kanssa” painottui 3,8 prosenttia verran kaikista motiiveista, ei mielestämme voi vetää johtopäätöstä, että yhteistyö herätti vain vähän kiinnostusta. Hakijoiden runsas määrä sinällään jo kertoo siitä, että kiinnostusta yhteistyöhön on. Tämän kategorian osalta voisi pitää yllätyksellisenä sitä, että yliopistoyhteistyö koettiin näinkin suuressa määrin arvona sinänsä.

Mitä opettajien ilmaisemat motiivit kertovat kenttäkouluverkostoyhteistyön edellytyksistä ja kehittämisestä? Ensinnäkin voidaan todeta, että harjoittelua koskeva yhteistyö on erittäin hyvä perusta yliopiston opettajankoulutuksen ja koulun väliselle kumppanuudelle. Harjoittelun sekä verkoston järjestämän ohjaajakoulutuksen kautta opettajat tulevat tietoisemmiksi yliopiston opettajankoulutuksen tavoitteista ja kykenevät linkittämään tätä tietoaan omaan kokemukseensa opettajuudesta. Harjoitteluyhteistyöstä voidaan vuosien myötä edetä myös erilaisiin tutkimus- ja kehittämis- ja täydennyskoulutushankkeisiin. Esimerkiksi jotkut ohjaavista opettajista ovat jo osoittaneet orastavaa kiinnostusta hakeutua jatko-opintoihin ja muutamat ovat ne jo aloittaneetkin.

Toiseksi motiivit kertovat siitä, että verkoston tulisi rakentua vastavuoroisuuden periaatteelle. Opettajat kokevat, että heillä on oman kokemuksensa ja kouluyhteisönsä kautta annettavaa opettajankoulutukselle. Yliopiston puolella puhuu tieteellinen tieto ja koulun puolella käytännön kokemus. Osapuolia kunnioittaen verkoston tulisi luoda tilanteita, joissa molemminpuolista asiantuntemusta voidaan hyödyntää yhtä arvokkaana. Yliopistopedagogiikan ja koulupedagogiikan erilaisten näkökulmien kohtaaminen on sekä kouluarkea että opettajankoulutusta rikastuttavaa.

Ammatillisen kehittymisen voimakas korostuminen motiiveissa on saman suuntainen kuin kokemukset muualla maailmassa (esim. Borthwick, 2003, Sandholz, 2002, Lopez-Real \& Kwan, 2005). Yhdysvalloissa PDS-kumppanuusohjelman keskeisimpiä tavoitteita ja tuloksia on opettajien ammatillinen kehittyminen opiskelijan ammatillisen kehittymisen rinnalla. Tämän pohjalta, kolmanneksi, voidaan todeta, että verkostoyhteistyön muodot tulisi rakentaa niin, että kollegiaaliset tilanteet ammatillisten kysymysten syventämiseksi, peilaamiseksi, ammentamiseksi, sitoutumiseksi sekä tuulettumiseksi olisivat verkoston järjestämissä tapaamisissa mahdollisia, siis muidenkin kuin harjoittelijoiden kanssa. Näistä esimerkkinä Hel- singin yliopiston kenttäkouluverkostossa ovat ohjaajakoulutuksessa toteutetut koti- ja vertaisryhmäkeskustelut, kaikille opettajankouluttajille suunnattu opetusharjoittelusymposiumi sekä ainetai koulutuskohtaiset yhteistyöseminaarit (Syrjäläinen \& Meri, 2007).

Hakulomake ohjaajakoulutukseen oli eräänlainen 'työnhakulomake'. Sellaisissahan on tapana antaa itsestä hyvä kuva ja tuoda esiin parhaat piirteet. Tehtävänanto korosti ohjaajaksi hakeutumisen motiiveja, joten on luonnollista, että silloin ilmaistaan sellaisia myönteisiä seikkoja, joilla arvellaan olevan merkitystä ohjaajia valittaessa. Kukaan vastaajista ei esimerkiksi ilmaissut motiivikseen itsekkäiksi tulkittavissa olevia syitä tai että työstä saa palkkion. On oletettavaa, että palkkio ulkoisena motiivina ei ole merkityksetön. Mikäli palkkiota ei olisi, ohjaajaksi hakeutuminen saattaisi olla vähäisempää. Motiivina ei myöskään mainittu sitä, että opiskelijat pitävät oppitunnit tiettynä ajanjaksona. Tämän voisi kuvitella olevan virkistävää vaihtelua opettajan työn arkeen ja helpottavan tuntien valmistelutyötä. Toisaalta opetustyön helpottuminen tuo ohjaustyötä tilalle.

Varsin paljon opettajien ilmaisemissa motiiveissa nousi esiin mielikuva- tai metaforakieltä. Otsikossamme käyttämä kultajyvä on yksi näistä. Eräs opettaja toteaa: "Kohtalaisen työkokemuksen jälkeen on mielenkiintoista pohtia opetusta ja kasvatusta yhdessä nuorten kanssa ja kenties löytää uusia kultajyviä.” Opetuksen ja kasvatuksen kysymyksiä pohditaan päätoimisesti sekä opettajankoulutuksessa että koulun arjessa. Kenttäkouluverkosto luo nyt polkuja näiden kahden organisaation väliseen maastoon kultajyvien ammentamiseksi tästä yhteistyöstä. Se edellyttää kuitenkin yliopistolta, kenttäkouluverkoston organisoijalta, pedagogista näkemystä siitä, miten nämä osapuolet on mielekästä saattaa yhteen.

\section{Lähteet}

Borthwick, A.C., Stirling, T., Nauman, A.D., \& Cook, D.L. (2003). Achieving successful school-university collaboration. Urban Education 38(3), 330-371.

Edwards, A., \& Mutton, T. (2007). Looking forward: rethinking professional learning through partnership arrengements in Initial Teacher Education. Oxford Review of Education 33(4), 503-519. 
Firestone, W. A., \& Fisler J. L. (2002). Politics, Community, and Leadership in a School-University Partnership. Educational administration Quarterly 38(4), 449-493.

Freese, A. R. (1999). The role of reflection on perservice teachers' development in the context of a professional development school. Teaching and Teacher Education 15(8), 895-909.

Hodkinson, H., \& Hodkinson, P. (1999). Teaching to learn, learning to teach? School-based non-teaching activity in an initial teacher education and training partnership scheme. Teaching and teacher education 15(3), 273-285.

Jyrhämä, R., \& Kronlund, T. (2003). Tutkimuksen ja opetuksen ykseys - haaste praktikumien ohjaajille. Teoksessa V. Meisalo (toim.), Aineenopettajankoulutuksen vaihtoehdot ja tutkimus 2002. Ainedidaktiikan symposiumi 1.2.2002 (s. 141-150). Helsingin yliopiston opettajankoulutuslaitoksen tutkimuksia 241.

Jyrhämä, R. (2006). The Function of Practical Studies in Teacher Education. In R. JakkuSihvonen \& H. Niemi (Eds.) Research-based Teacher Education in Finland - Reflections by Finnish Teacher Educators (pp. 51-69). Turku: Finnish Educational Research Association.

Järvinen, A., Koivisto, T., \& Poikela, E. (2000). Oppiminen työssä ja työyhteisössä. WSOY.

Kirschenbaum, H. \& Reagan, C. 2001. University and urban school partnerships. An analysis of 57 collaborations between university and a city school district. Urban Education 36(4), 479-504.

Loima, J. (toim) 2004. Theoria et Praxis. http:// www.vink.helsinki.fi/files/Theoria_alkusanat.html

Lopez-Real, F., \& Kwan T. (2005). Mentors perceptions of their own professional development during mentoring. Journal of Education for Teaching 31(1), 15-24.

Luukkainen, O. (2005). Opettajan matkakirja tulevaan. Jyväskylä: PS-kustannus

Rice, E.H. (2002). The collaboration process in professional development schools. Results of a meta-ethnography, 1990-1998. Journal of Teacher Education 53(1), 55-67.

Sandholz, J. H. (2002). Inservice training or professional development: contrasting opportunities in a school/university partnership. Teaching and Teacher Education 18(7), 815-830.
Silkelä, R. (toim.) (2003). Tutkimuksia opetusharjoittelun ohjauksesta. Suomen harjoittelukoulujen vuosikirja n:o 1. Joensuu: Joensuun yliopistopaino.

Stevens, D. D. (1999). The ideal, real and surreal in school-university partnerships: reflections of a boundary spanner. Teaching and Teacher Education 15(3), 287-299.

Sutherland, L. M., Scanlon, L. A., \& Sperring A. (2005). New directions in preparing professionals: examining issues in engaging students in communities of practice through a school-university partnership. Teaching and Teacher Education 21(1), 79-92.

Syrjäläinen, E., \& Meri, M. (2007). Kenttäkouluverkosto osana opettajankoulutusta. Pedagogica 24. Helsingin yliopiston käyttäytymistieteellinen tiedekunta.

Tynjälä, P. (2004). Asiantuntijuus ja työkulttuurit opettajan ammatissa. Kasvatus 35(2), 174-190.

Tynjälä, P. (2007). Integratiivinen pedagogiikka osaamisen kehittämisessä. Teoksessa H. Kotila, A. Mutanen \& M. V. Volanen (toim.) Taidon tieto (11-36). Helsinki. Edita.

Uusikylä, K. (1990). Akateemiseksi luokanopettajaksi kehittyminen. Seurantatutkimus Helsingin yliopiston opettajankoulutuslaitoksessa 1979-1989. Tutkimuksia 83. Helsingin yliopiston opettajankoulutuslaitos.

Winitzky, N., Stoddard, T., \& O’Keefe, P. (1992). Great expectations: Emergent professional development schools. Journal of Teacher Education 43(1), 3-18.

Väisänen, P. \& Atjonen, P. (toim.) (2005). Kohtaamisia ja kasvun paikkoja opetusharjoittelussa. Vuoropuhelua ohjauksen kehittämisestä. Suomen harjoittelukoulujen vuosikirja n:o 3. Joensuu: Joensuun yliopistopaino.

Välijärvi, J. (2006). Kansankynttilästä tietotyön ammattilaiseksi. Opettajan työn yhteiskunnallisten ehtojen muutos. Teoksessa A. R. Nummenmaa \& J. Välijärvi (toim.) Opettajan työ ja oppiminen (s. 9-26). Jyväskylä: Koulutuksen tutkimuslaitos.

Zeichner, K. (1990). Changing Directions in the Practicum: looking ahead to the 1990s. Journal of Education for Teaching, 16(2), 105-132.

Artikkeli saapui toimitukseen 26.3.2008. Se hyväksyttiin julkaistavaksi 22.9.2008. 